\title{
Spatial distribution of snakebites in the State of Ceará, Brazil (2008-2018)
}

\author{
Distribuição espacial das picadas de serpente no Estado do Ceará, Brasill (2008 - 2018) \\ Distribución espacial de mordeduras de serpiente en el Estado de Ceará, Brasil (2008-2018)
}

Received: 08/03/2021 | Reviewed: 08/08/2021 | Accept: 08/09/2021 | Published: 08/14/2021

\author{
Jacqueline Ramos Machado Braga \\ ORCID: https://orcid.org/0000-0003-4417-8591 \\ Universidade Federal do Recôncavo da Bahia, Brazil \\ E-mail: jacquebraga@ufrb.edu.br \\ Relrison Dias Ramalho \\ ORCID: https://orcid.org/0000-0002-8736-7213 \\ Secretaria de Saúde do Ceará, Brazil \\ E-mail: relrisondias@gmail.com \\ José Cleidvan Cândido de Sousa \\ ORCID: https://orcid.org/0000-0003-2645-728X \\ Secretaria de Saúde do Ceará, Brazil \\ E-mail: josecleidvan@gmail.com \\ Luis Eduardo Meira Faria \\ ORCID: https://orcid.org/0000-0001-8378-7483 \\ Universidade Federal do Recôncavo da Bahia, Brazil \\ E-mail: ledmfaria@gmail.com
}

\begin{abstract}
Snakebites represent an important, though neglected, public health problem especially in the Northeast of Brazil. There is still a large number of underreported cases, the collection of epidemiological data is deficient, and the ecological and epidemiological knowledge of this envenomation remains limited due to the lack of updated regional and local information. This study describes the epidemiological profile of snakebites recorded by the Notifiable Diseases Information System from 2008 to 2018 in the state of Ceará. The data were organized according to the municipalities of the health macro-regions, considering the variables: sex, snake, gravity and deaths. A total of 8,233 cases was found, with an annual incidence of 8.6/100,000 inhabitants, and a higher prevalence of accidents caused by Bothrops snakes (64\%), in men (87.4\%) in the Sobral region (25.5\%). However, the highest incidence rate was found in the Sertão Central (299.7/100,000). Most cases were considered mild (62\%), but the mortality rate was $0.07 / 100,000$ and the case-fatality rate was $0.8 \%$. Among the most affected municipalities, cities like Tauá (1.3\%), Sobral $(8.1 \%)$ and Fortaleza $(8.5 \%)$ are concerning, considering that the case-fatality rates were above the national average $(1 \%)$. Snakebites in Ceará follow a pattern similar to that of other states in the Northeast, with a high frequency of incidents where the causative snake is not identified (16\%). Considering the gravity of snakebites, studies that evaluate the anthropic and environmental influence in the distribution of cases may help to define priority risk areas, to improve health surveillance and patient care.
\end{abstract}

Keywords: Bothrops; Envenomation; Northeast.

\section{Resumo}

Picadas de serpentes representam um importante, embora negligenciado, problema de saúde pública, principalmente no Nordeste do Brasil. Ainda é grande o número de casos subnotificados, a coleta de dados epidemiológicos é deficiente, e o conhecimento ecológico e epidemiológico desse envenenamento permanece limitado, devido à falta de atualização de informações regionais e locais. Este estudo descreve o perfil epidemiológico das picadas de serpentes registradas pelo Sistema de Informação de Agravos de Notificação de 2008 a 2018 no estado do Ceará. Os dados foram organizados segundo os municípios das macrorregiões de saúde, considerando as variáveis: sexo, serpente, gravidade e óbitos. Foram encontrados 8.233 casos, com incidência anual de 8,6/100.000 habitantes e maior prevalência de acidentes botrópicos $(64 \%)$, em homens $(87,4 \%)$ na região de Sobral $(25,5 \%)$. Porém, a maior taxa de incidência foi encontrada no Sertão Central (299,7/100.000). A maioria dos casos foi considerada leve (62\%), mas a taxa de mortalidade foi de $0,07 / 100.000$ e taxa de letalidade de $0,8 \%$. Entre os municípios mais atingidos, cidades como Tauá $(1,3 \%)$, Sobral $(8,1 \%)$ e Fortaleza $(8,5 \%)$ são preocupantes, visto que as taxas de letalidade ficaram acima da média nacional $(1 \%)$. As picadas de serpentes no Ceará seguem um padrão semelhante ao de outros estados do Nordeste, com alta frequência de incidentes onde a serpente causadora não é identificada (16\%). Considerando a gravidade das picadas de serpentes, estudos que avaliem a influência antrópica e ambiental na distribuição dos casos podem auxiliar na definição de áreas de risco prioritárias, para melhorar a vigilância em saúde e o atendimento ao paciente.

Palavras-chave: Bothrops; Envenenamento; Nordeste. 


\begin{abstract}
Resumen
Las mordeduras de serpientes representan un problema de salud pública importante, aunque desatendido, especialmente en el noreste de Brasil. El número de casos infrarreportados sigue siendo elevado, la recopilación de datos epidemiológicos es deficientes y el conocimiento ecológico y epidemiológico de esta intoxicación sigue siendo limitado, debido a la falta de información regional y local actualizada. Este estudio describe el perfil epidemiológico de las mordeduras de serpientes registradas por el Sistema de Información de Enfermedades Notificables de 2008 a 2018 en el estado de Ceará. Los datos se organizaron según los municipios de los macrorregiones de salud, considerando las variables: género, culebra, severidad y muertes. Se encontraron 8.233 casos, con una incidencia anual de 8,6 / 100.000 habitantes y una mayor prevalencia de accidentes botrópicos (64\%) en hombres (87,4\%) en la comarca de Sobral (25,5\%). Sin embargo, la tasa de incidencia más alta se encontró en el Sertão Central (299,7 / 100.000). La mayoría de los casos se consideraron leves (62\%), pero la tasa de mortalidad fue de 0,07 / 100.000 y la tasa de letalidad fue de $0,8 \%$. Entre los municipios más afectados, ciudades como Tauá $(1,3 \%)$, Sobral $(8,1 \%)$ y Fortaleza $(8,5 \%)$ son preocupantes, ya que las tasas de letalidad estuvieron por encima de la media nacional (1\%). Las mordeduras de serpientes en Ceará siguen un patrón similar al de otros estados del noreste, con una alta frecuencia de incidentes donde no se identifica la serpiente causante (16\%). Considerando la gravedad de las mordeduras de serpientes, los estudios que evalúen la influencia antropogénica y ambiental en la distribución de casos pueden ayudar a definir áreas de riesgo prioritarias, con el fin de mejorar la vigilancia de la salud y la atención al paciente.
\end{abstract}

Palabras clave: Bothrops; Envenenamiento; Noreste.

\title{
1. Introduction
}

Every day, an average of 7400 people are bitten by snakes, representing between 81,000 and 138,000 deaths, annually, worldwide, with about 400,000 disabilities such as amputations and post-traumatic stress disorder (Minghui et al., 2019, Gutiérrez et al., 2017). Most of these accidents are distributed in tropical and subtropical regions of the world, where there is a great diversity of snakes coexisting with the human peasant population with limited access to health and rural technology (Chippaux, 2012, Mise et al., 2016). Although in 2009 the World Health Organization (WHO) included snake bite on the list of Neglected Tropical Diseases (NTDs), it left this list in 2013, returning in 2017 as a global strategy to have the number of deaths and disabilities caused by this envenomation by 2030 (WHO, 2019). However, some studies argue that snakebites are not neglected (Simpson \& Norris 2009), but underestimated and fundamentally poorly understood (Fry, 2018).

In Central and South American countries, most of the available data on snakebites is fragmentary and not very representative (Chippaux, 2017). Among the South American countries, Brazil is the one that reports the highest number of cases of snakebites per year (Gutiérrez et al. 2017), registering 265,701 incidents in 2019 (Sinan, 2019). In Brazil, of the 405 species of snakes distributed throughout the territory, only 76 of them (19\%) are considered of medical importance (WHO, 2019). However, most research is focused in bioprospecting biologically active molecules from the venom of these animals and developing antivenoms. As a result, the ecological and epidemiological knowledge of snakebites remains limited mainly in the states of the Northeast region, since there is still a lack of updated regional and local information, compatible with medical relevance, which hinders efforts to accurately map and mitigate these incidents (Murray et al., 2020).

Despite the existence of mandatory reporting systems in Brazil containing information on the epidemiological profile of snakebites in the State of Ceará, updated local and/or regional epidemiological information compatible with the medical importance of this envenomation is lacking. In addition, in the Northeast region there is still a large number of underreported cases and the collection of epidemiological data is deficient (Tavares et al., 2020). There are only three epidemiological studies in the literature that address snakebites in the state of Ceará (Feitosa et al., 1997, Albuquerque et al., 2013, Belmino, 2015) and in none of them the incidents are distributed by health macro-regions. Considering that snakebite rates follow considerable regional variation, the scarcity and outdated information on this type of notification, associated with the high number of victims, the importance of regionalized epidemiological mapping is evident to update knowledge and help to improve preventive measures and case management. Thus, this study aims to map the distribution of snakebites for health macroregions in the State of Ceará between 2008 and 2018. 


\section{Methodology}

This is an epidemiological descriptive, retrospective, cross-sectional study, of quantitative approach of snakebite cases recorded between January 2008 and December 2018 in the state of Ceará, Brazil.

\subsection{Study area}

The state of Ceará is located in the north of the northeast region of Brazil and is bordered by the Atlantic Ocean (North), Rio Grande do Norte and Paraíba (East), Pernambuco (South), and Piauí (West). Ceará has a total area of 148,920.4 $\mathrm{km}^{2}$, and an estimated population of 9,132,078 inhabitants (IBGE, 2019). The climate is predominantly hot semi-arid, characterized by scarce and irregular rainfalls (IBGE, 2019).

\subsection{Data collection}

The data were obtained through the records of the Information System for Notifiable Diseases (SINAN), nationwide, and grouped according to the health macro-regions (Fortaleza, Sobral, Cariri, Sertão Central and Litoral Leste/Jaguaribe), delimited by the Health Department of the state of Ceará (SESA). The location of the accidents (macro-health region and municipality) was considered for the analysis, associated with variables such as age, sex, snake identification, severity of the accident and death. Population data were obtained from the Brazilian Institute of Geography and Statistics (IBGE), based on the National Population Census (2010), and the estimated population for the inter-census years.

\subsection{Ethics Statement}

The present study followed the rules set out in the Resolution from the National Health Council No. 466 from December 12th, 2012, which states that research involving only secondary data in the public domain, without nominal identification of the research participants, does not require appreciation by a research ethics committee involving human beings.

\subsection{Statistical analysis}

The data were compiled, tabulated and analyzed using descriptive statistics (BiostatTGV software) to determine simple (n) and relative (\%) frequencies and the results were presented in the form of contingency tables using Microsoft Excel 2019 software. The incidence, mortality and lethality rates were also calculated and it was used the estimated population for the state of Ceará between 2008 and 2018 as the standard. The chi-square test $\left(\chi^{2}\right)$ was used to test the association among variables to the significance level $\mathrm{p}<0.05$. Microsoft Excel 2019 was used to create tables and graphics. To create the distribution maps, the QGIS desktop 2.18.18 with GRASS 7.4.0 program was used.

\section{Results and Discussion}

There have been reported 8,233 cases of snakebites in the State of Ceará, from January 2008 to December 2018, which represents an average annual incidence of $8.6 / 100,000$ inhabitants and 3\% (748.5 \pm 195.1$)$ of all snakebites registered in Brazil for the same period (Table 1). 
Table 1 - Epidemiological variables and temporal distribution of snakebites in the state of Ceará, and in its municipalities $(n=184)$ according to health macro-regions $(2008-2018)$.

\begin{tabular}{|c|c|c|c|c|c|c|}
\hline Year & Ceará snakebites & $\begin{array}{c}\text { Brazil } \\
\text { snakebites }\end{array}$ & $\begin{array}{c}\text { Ceará } \\
\text { representativity }\end{array}$ & $\begin{array}{c}\text { Mortality/ } \\
100,000 \\
\text { inhabitants* }\end{array}$ & $\begin{array}{c}\text { Case- } \\
\text { fatality } \\
\text { rate }(\%)\end{array}$ & $\begin{array}{c}\text { Incidence/ } \\
100,000 \text { inhabitants* }\end{array}$ \\
\hline 2008 & 721 & 27,685 & $3 \%$ & 0.06 & 0.7 & 8.5 \\
\hline 2009 & 894 & 29,638 & $3 \%$ & 0.06 & 0.6 & 10.5 \\
\hline 2010 & 874 & 29,661 & $3 \%$ & 0.05 & 0.5 & 10.3 \\
\hline 2011 & 686 & 30,101 & $2 \%$ & 0.07 & 0.6 & 8.0 \\
\hline 2012 & 585 & 28,340 & $2 \%$ & 0.07 & 1.0 & 6.8 \\
\hline 2013 & 470 & 27,291 & $2 \%$ & 0.05 & 0.9 & 5.4 \\
\hline 2014 & 456 & 26,145 & $2 \%$ & 0.07 & 1.3 & 5.2 \\
\hline 2015 & 666 & 27,113 & $2 \%$ & 0.12 & 1.7 & 7.5 \\
\hline 2016 & 890 & 26,561 & $3 \%$ & 0.10 & 1.0 & 9.9 \\
\hline 2017 & 1,012 & 28,747 & $4 \%$ & 0.09 & 0.8 & 11.2 \\
\hline 2018 & 979 & 28,641 & $3 \%$ & 0.02 & 0.2 & 10.8 \\
\hline$\Sigma$ & 8,233 & 309,923 & & & & \\
\hline$\overline{\text { Averag }}$ & SD $748.5 \pm 195.1$ & $28.174 .8 \pm 1,323.1$ & $3 \%$ & 0.07 & 0.8 & 8.6 \\
\hline
\end{tabular}

Acarapé (2), Ararendá (4), Amontada (17), Apuiarés (1), Aquiraz (1), Aracoiaba (9), Aratuba (105), Barreira (3), Baturité (13), Capistrano (13), Caucaia (41), Euzébio (3), Fortaleza (258), General Sampaio (1), Guaiúba

Fortaleza (3), Guaramiranga (13), Itaitinga (4), Itapagé (4), Itapipoca (29), Itapiúna (130), Jaguaretama (139), $\mathrm{n}=1,369(16.6 \%)$ Jaguaruana (45), Maracanaú (23), Maranguape (26), Miraíma (4), Morada Nova (177), Mulungu (20), Pacatuba (6), Pacoti (12), Palhano (45), Palmácia (2), Paracuru (10), Paraipaba (7), Pentecoste (11), Redenção (3), Russas (156), São Gonçalo do Amarante (33), São Luiz do Curu (3), Tejussuoca (11), Trairí (2), Tururu (4), Umirim (0) e Uruburetama (3). Total: 42 municipalities.

Ararendá (9), Alcântaras (4), Acaraú (3), Barroquinha (6), Bela Cruz (19), Camocim (8), Carnaubal (45), Cariré (6), Catunda (12), Chaval (2), Coreaú (9), Crateús (90), Croatá (68), Cruz (7), Forquilha (6), Frecheirinha (13), Graça (6), Granja (29), Groaíras (2), Guaraciaba do Norte (145), Hidrolândia (7), Ibiapina

Sobral $\mathrm{n}=2,097(25.5 \%)$ (69), Independência (152), Ipaporanga (17), Ipú (39), Ipueiras (63), Irauçuba (8), Itarema (21), Jijoca de Jericoacoara (2), Marco (4), Martinópole (1), Massapê (4), Meruoca (2), Monsenhor Tabosa (75), Moraújo (0), Morrinhos (10), Mucambo (3), Nova Russas (9), Novo Oriente (24), Pacujá (1), Pires Ferreira (3), Poranga (45), Quiterianópoles (47), Reriutaba (8), Santa Quitéria (27), Santana do Acaraú (4), São Benedito (62), Senador Sá (4), Sobral (74), Tamboril (111), Tianguá (233), Ubajara (184), Uruoca (2), Varjota (2) e Viçosa do Ceará (291). Total: 55 municipalities.

Abaiara (2), Acopiara (61), Altaneira (10), Antonina do Norte (4), Araripe (41), Assaré (10), Aurora (27), Baixio (1), Barbalha (107), Barro (11), Brejo Santo (46), Campos Sales (23), Caririaçu (27), Cariús (55),

Cariri $\mathrm{n}=1,871(22.7 \%)$ Catarina (107), Cedro (44), Crato (164), Deputado Irapuan Pinheiro (63), Farias Brito (73), Granjeiro (14), Icó (80), Iguatu (54), Ipaumirim (7), Jardim (44), Jati (17), Juazeiro do Norte (23), Jucás (56), Lavras da Mangabeira (25), Mauriti (63), Milagres (26), Missão Velha (38), Mombaça (57), Nova Olinda (25), Orós (29), Penaforte (11), Piquet Carneiro (30), Porteiras (51), Potengi (14), Quixelô (24), Saboeiro (64), Salitre (64), Santana do Cariri (73), Tarrafas (18), Umari (5) e Várzea Alegre (83). Total: 45 municipalities.

Sertão Central $\mathrm{n}=1,891(23.0 \%)$ Aiuaba (51), Arneiroz (47), Banabuiú (101), Boa Viagem (140), Canindé (180), Caridade (94), Choró (51), Ibaretama (35), Ibicuitinga (13), Itatira (151), Madalena (89), Milhã (24), Parambu (69), Paramoti (8), Pedra Branca (108), Quixadá (172), Quixeramobim (136), Senador Pompeu (30), Solonópole (87) e Tauá (305). Total: 20 municipalities.

Alto Santo (54), Aracati (180), Beberibe (25), Cascavel (8), Chorozinho (2), Ererê (14), Fortim (26),

Litoral Leste/Jaguaribe $\mathrm{n}=979(11.9 \%)$
Horizonte (8), Icapuí (81), Iracema (50), Itaiçaba (28), Jaguaribara (44), Jaguaribe (151), Limoeiro do Norte (101), Ocara (6), Pacajús (11), Pereiro (35), Pindoretama (6), Potiretama (29), Quixeré (54), São João do Jaguaribe (26) e Tabuleiro do Norte (40). Total: 22 municipalities. 
The distribution of snakebites varies widely among the population of different states and geographic regions of Brazil and according to the geographical distribution of Brazilian snake species of medical importance (Belmino, 2015). According to data from the Ministry of Health, the Northeast region ranked second in the number of cases of snakebites, rising from 2,658 in 2000 to more than 95,000 cases in 2019 (25\% of the total in Brazil) (Da Costa et al., 2019). However, the Northeast led the ranking in the number of deaths in 2019 (SINAN, 2019). The highest number of incidents was reported in 2017 , with 1012 cases (SINAN, 2019). In general, despite the variations observed in the incidence throughout the historical series, it is evident in Table 1 that there was no increase in incidence, considering that there was a proportional increase in the population of Ceará.

Sixty-four deaths as result of snakebites were recorded in the state of Ceará, with a frequency of 2.3 deaths / year, an average mortality rate of 0.07 / 100,000 inhabitants and a lethality rate of $0.8 \%$ (Table 1). The results of snake incidents found in our study are similar to studies carried out in other Northeastern states, such as Bahia (Mise et al., 2016), Rio Grande do Norte (Da Costa et al., 2019), Piauí (Oliveira et al., 2015) and Paraíba (Lacerda et al., 2017). Incidence and mortality increased slightly and appeared to follow demographic trends. Despite the high case-fatality rate found in Fortaleza and Sobral, the mortality rates (0.8 and 3.4 per hundred thousand, respectively) were lower than those in Tauá (6.9), the municipality with the highest mortality rate in Ceará (Table 1).

Overall, most incidents affected men $(n=7184,87.4 \%)$ and there was a significant difference $(\chi 2=2914.6, \mathrm{p}<0.05)$ compared to the number recorded for women $(n=2008,12.6 \%)$. Most incidents were classified as mild $(n=4,665,62 \%)$, followed by moderate $(n=1,918,25 \%)$ and severe $(n=304,4 \%)(\chi 2=4346.6, p<0.05)$. The disproportion between men and women in cases of snakebites is probably related to the difference in the risks of human activities and/or distribution of snakes (Chippaux, 2015). In this way, snakebites could be the result of agricultural activities, assuming that they also involve more men than women. According to Da Silva et al. (2015), the main victims of snakebites in Brazil are men of working age (20 to 59 years old). These data agree with the results of the present study for the state of Ceará. Snakebite mortality in Brazil is associated with agricultural work, advanced age, delayed treatment time and inadequate antivenom therapy, characterizing this envenomation as an agricultural occupational health problem (Mise et al., 2019, Mise et al., 2016).

The macro-regions of Sobral $(\mathrm{n}=2,097,25.5 \%)$, Sertão Central $(\mathrm{n}=1,891,23.0 \%)$ and Cariri $(\mathrm{n}=1,871,22.7 \%)$ recorded the highest number of cases $(\chi 2=509.06, \mathrm{p}<0.05)$ (Table 1). However, in the historical series, the incidence was higher in the macro-regions of Sertão Central (299.7) and Litoral Leste / Jaguaribe (183.9) (Figure 1). Chaves et al. (2015) suggest that snakebites are influenced by climatic factors such as El-Niño, and are more frequent at high temperatures and with poverty indicators, but decrease with altitude, factors that correspond to the characteristics of Ceará's hotspots.

The increase in cases of snakebites occurs in the rainiest and hottest periods, coinciding with the period of greatest human activity in the field, and the reproductive period of snakes (Fry, 2018). It is suggested that climate changes that have occurred in recent years in the Northeast region, represented by increasingly prolonged and extreme drought periods, should change the pattern of the biodiversity and the distribution of reptiles and amphibians (Da Costa et al., 2019). In addition, environmental changes can alter the availability of food and the ability of snakes to survive (Lourenço-de-Moraes et al., 2019). Among the main climatic changes observed in the Ceará, the drought period of the last years, and changes in the characteristics of the biomes can interfere in defining snakebites demography, considering that $100 \%$ of the territory of Ceará is within the Desertification Susceptible Areas (DSAs) (Da Costa et al., 2019). 
Figure 1 - Incidence/100,000 inhabitants (blue bars) and mortality rates/100,000 inhabitants (green bars) by snakebites in the health macro-regions (map) of state of Ceará, Brazil (2008 - 2018).

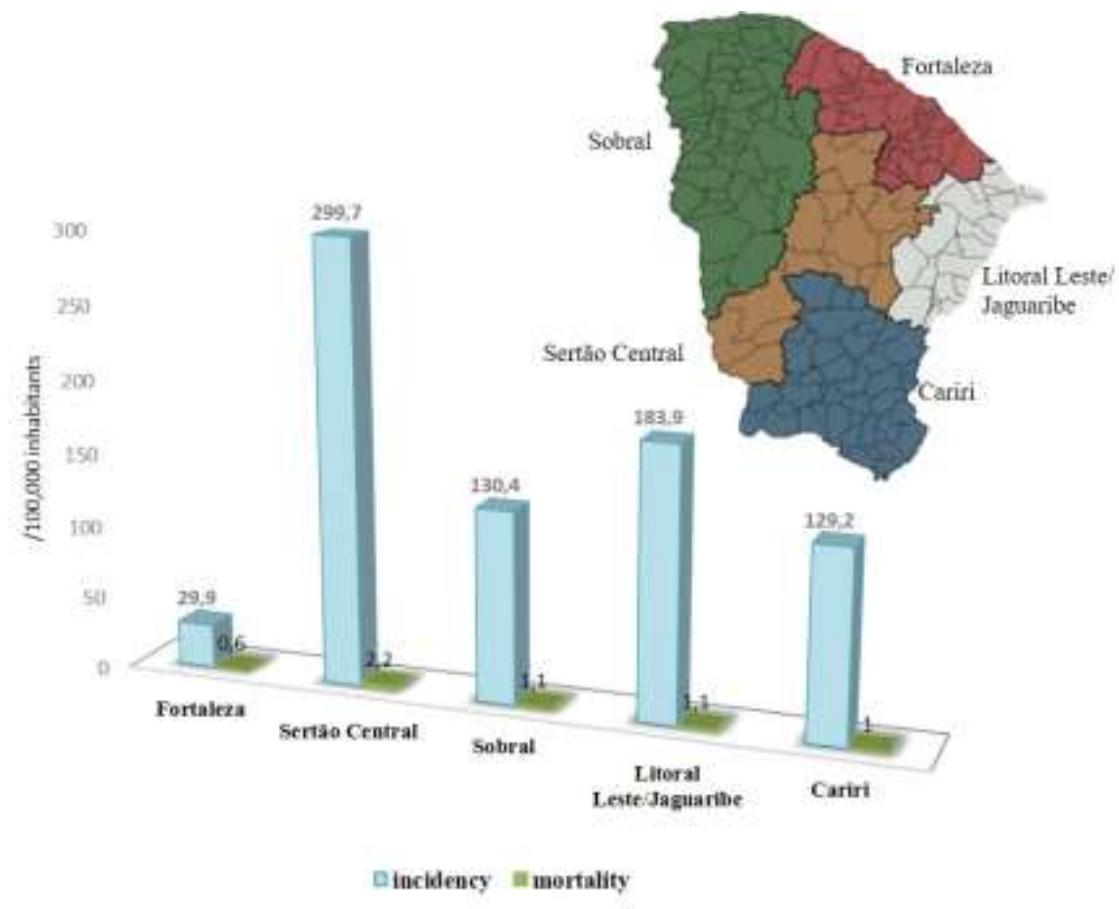

Fonte: Ministério da Saúde-SINAN (2019).

The long periods of drought recorded in Ceará (2012-2018), associated with the management and incorrect use of the soil, resulted in the degradation of important environmental components for the balance and diversity of fauna and flora (Borges-Nojosa et al., 2019). The incidence of snakebites is a consequence of the animal's biology and behavior, which explains its presence and abundance in a given location, but also of human activities that put the victim in contact with the snake (ChipPaux, 2015). Disordered deforestation, extraction, burning, intensive land use in agriculture, poorly conducted irrigation and overgrazing are some of the activities responsible for land degradation (Da Costa et al., 2019). The anthropic factors that cause habitat loss and degradation vary according to the country's region and economic profile, but the most significant ones are related to agricultural activities (Borges-Nojosa et al., 2019). Thus, the reduction in habitat availability tends to increase the chances of contact between snakes and humans.

Bothrops envenomation was the most frequent in Ceará $(5,276$ cases, $64 \%, \chi 2=11391$, p <0.05), with an annual average of $479.6 \pm 125$. Incidents by Crotalus were responsible for 713 cases (9\%), followed by Micrurus (169 cases, $2 \%$ ) and Lachesis (236 cases, $0.33 \%$ ) (Figure 2). Incidents with non-venomous snakes $(\mathrm{n}=660)$ represented $8 \%$ of the total recorded in the studied period, and the number of incidents with unidentified snakes $(n=1,324)$ represented a high percentage of the total records (16\%), showing a growth trend of these accidents from 2015 (Figure 2). These results correspond to the data of SINAN (2019) also for the Northeast region. Our study revealed a similar pattern for Ceará, but the percentage of incidents in which the snake was not identified is worrying, considering that this is an important for antivenom therapy. Lira-da-Silva et al. (2009) suggests that the high frequency of bothropic incidents in the Northeast is justified by the fact that $50 \%$ of Brazilian Bothrops species occur in this region. 
Figure 2 - Distribution of snakebites cases according to the causative snake, Ceará- Brazil (2008 - 2018). Incidents in which the causative snake was not identified were excluded from the graph.

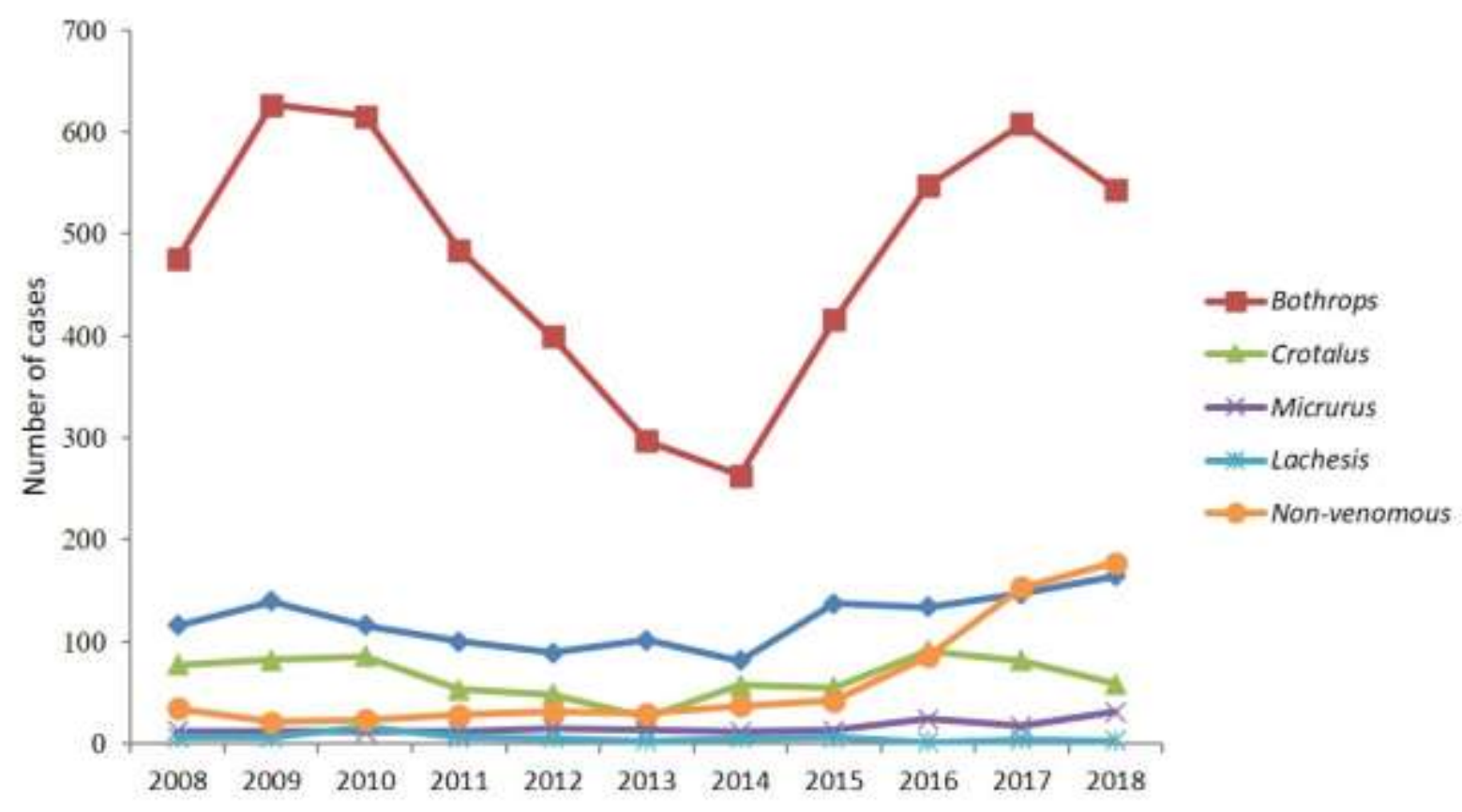

Fonte: Ministério da Saúde -SINAN (2019).

Incidents involving Bothrops (Figure 3A) and Crotalus (Figure 3B) were more widely distributed in the state of Ceará, being concentrated in the macro-regions of Sobral and Sertão Central. The municipalities of Ceará identified as hotspots for bothropic envenomation were Aracati, Crato, Guaraciaba do Norte, Independência, Jaguaretama, Morada Nova, Quixadá, Tauá, Tianguá, Ubajara and Viçosa do Ceará ( $\geq 100$ cases). The largest number of records of crotalic incidents ( $\geq 50$ cases) was found in Fortaleza and Viçosa do Ceará. It is known that in the state of Ceará most municipalities dispose of their waste in landfills (Bastos et al., 2017), so the high rate of bothropic incidents can be explained by the enormous adaptive plasticity of these snakes, allowing them to also inhabit forested or deforested areas occupied by humans (Bochner et al., 2014).

The presence of Bothrops snakes in precarious urban areas in Brazilian municipalities can occur considering that they feed mainly on small rodents, abundant in these places, but also in wealthier neighborhoods that border natural preservation areas, offering shelter for snakes, and creating the conditions for the so-called "urbanization of snakebites" (França \& França, 2019, Bochner et al., 2014). Interestingly Mise et al. (2007) showed that, although Bothrops are nocturnal snakes, most cases registered in the state of Bahia occurred during the day, showing the greater contact of man with these animals in periods of foraging and thermoregulation. 
Figure 3 - Snakebites in the municipalities $(\mathrm{n}=184)$ of the state of Ceará, considering snake genus: Bothrops (A), Crotalus (B), Lachesis (C) and Micrurus (D) (2008-2018). The maps show the color scales of distribution of number of cases.
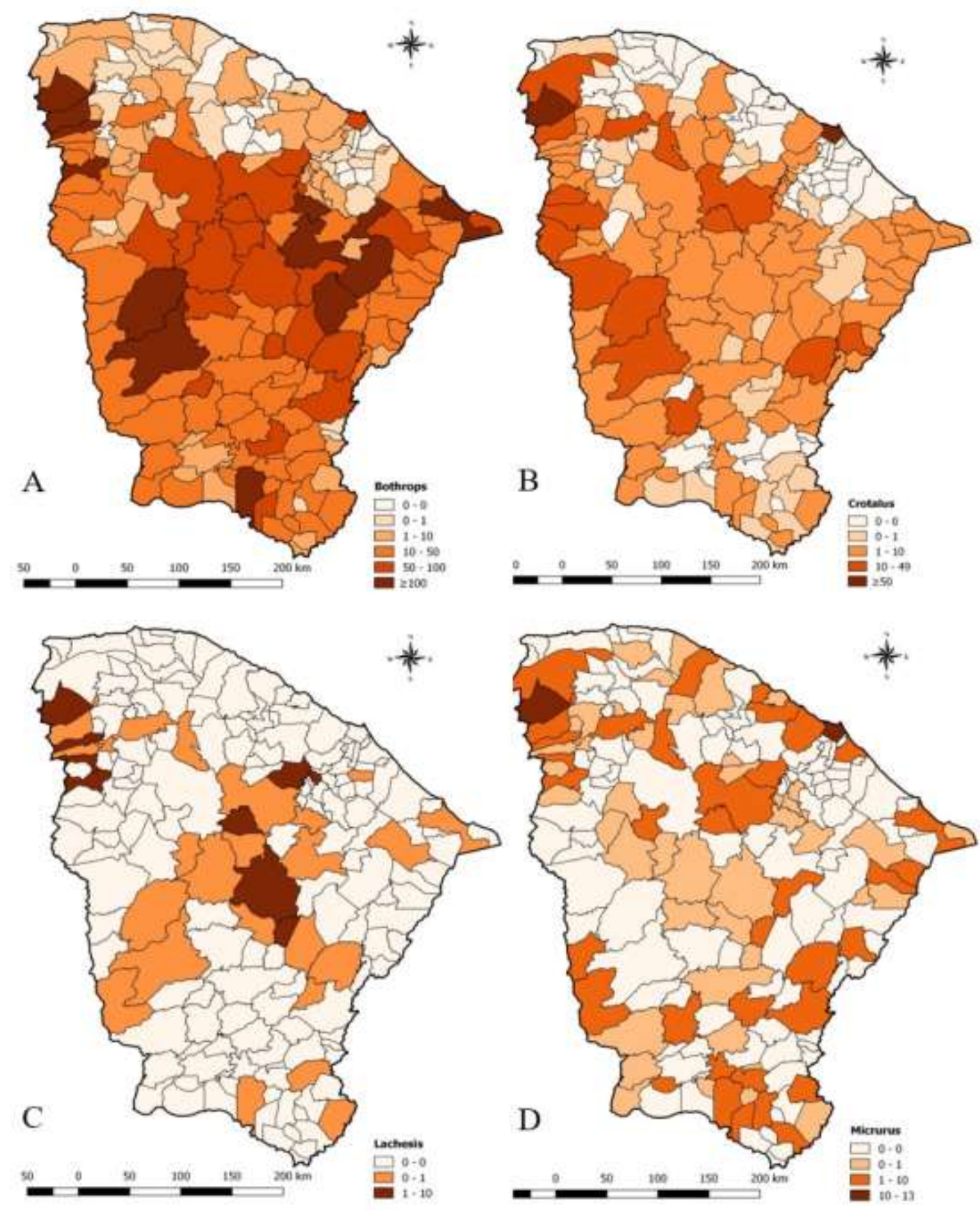

Fonte: Ministério da Saúde -SINAN (2019).

In Brazil, the genus Crotalus is widely distributed and has a diet characterized by an extreme specialization in endothermic preys, such as rodents, because of its abundance throughout the year (Hoyos \& Almeida-Santos, 2016). Our study revealed the wide distribution of Crotalus in the state of Ceará and the literature has already described that these snakes tend to occupy areas disturbed by human activities, which include landscape mosaics as original habitats, new environments and urban and agricultural areas.

In the Brazilian semi-arid region, where water is unpredictable, snakes may have morphological, physiological, behavioral and ecological adaptations to survive in this scenario (Da Costa et al., 2019). A recent study revealed that the diet is 
more important than the habitat to explain the partitioning of ecological niches by snakes, and thus, the coexistence of different species would be possible due to a high overlap in a specific niche dimension (microhabitat) would necessarily be possible due to a high overlap in a specific niche dimension (diet), which would avoid exclusion by competition (Di Pietro et al., 2020). This hypothesis could perhaps explain the high number of incidents caused by Bothrops in extremely arid macro regions such as the Sertão Central, an environment predominantly preferred by snakes of the genus Crotalus.

Incidents involving Micrurus (Figure 3C) showed great dispersion, but with an incidence and geographical concentration comparable to Lachesis, whose records were concentrated in the Sertão Central (Figure 3D). Fortaleza and Viçosa do Ceará were the main hotspots of incidents by Micrurus $(\mathrm{n}=10-12)$ and the incidents by Lachesis were concentrated in the municipalities of Caridade, Guaraciaba do Norte, Itatira, Ipueiras, Milhã, Quixeramobim, São Paulo. Benedito, Ubajara and Viçosa do Ceará $(n=1-10)$. Despite the great dispersion of accidents caused by Micrurus, due to its less aggressive behavior, the number of recorded incidents was low. Similar results in Paraíba and the Brazilian Amazon suggest that Micrurus appears to have a high degree of environmental plasticity, living well in both natural and anthropogenic environments (França \& França, 2019).

When we individually analyze the health macro-regions, we found that Sobral concentrates the municipalities with the highest number of records of snakebite in Ceará (Guaraciaba do Norte, Independência, Tamboril, Tianguá, Ubajara and Viçosa do Ceará) (186.0 \pm 50.7 cases). On second place is Sertão Central region (Barnabuiú, Boa Viagem, Canindé, Itatira, Pedra Branca, Quixadá, Quixeramobim and Tauá) (162.0 \pm 43.0 cases), followed by Fortaleza (Aratuba, Fortaleza, Itapiúna, Jaguaretama, Morada Nova and Russas) (160.8 \pm 37.8 cases), Litoral Leste / Jaguaribe (Aracati, Jaguaribe and Limoeiro do Norte) (144.0 \pm 28.7 cases) and Cariri (Barbalha, Catarina and Crato) $(126.0 \pm 25.3$ cases). Figure 4 shows that of the 184 municipalities in the state of Ceará, only ten represent $21.1 \%(\mathrm{n}=1738)$ of the total records of snakebites for the period, highlighting Tauá $(\mathrm{n}=305)$, Viçosa do Ceará $(\mathrm{n}=291)$ and Tianguá $(\mathrm{n}=233)$.

Figure 4 - Distribution of snakebite cases by snake genus among the municipalities of the state of Ceará with the highest frequency of occurrence (2008-2018).

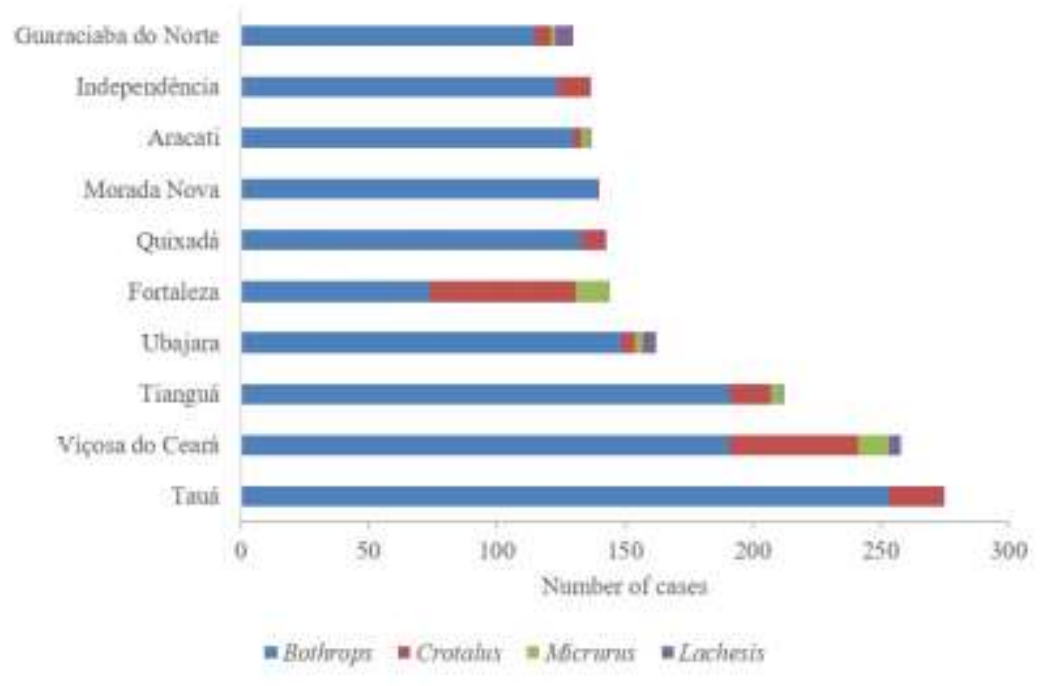

Fonte: Ministério da Saúde -SINAN (2019).

The macro-region of Fortaleza had a higher case-fatality rate $(\mathrm{n}=1396,1.7 \%)$ in relation to Sobral $(\mathrm{n}=2097,0.7 \%)$ and Sertão Central $(\mathrm{n}=1891,0.7 \%)$ together. The municipality of Tauá had the highest number of snakebites notifications $(\mathrm{n}=$ $305)$, and the case-fatality rate (1.3\%) was higher than the average for the state of Ceará $(0.8 \%)$. Therefore, the case-fatality 
rate of municipalities such as Tauá (1.3\%), Fortaleza (8.5\%) and Sobral (8.1\%) are worrying, considering that they were also higher than the national average (1.0\%) (SINAN, 2019).

The different snakebite patterns presented by the various health macro-regions of Ceará suggest that snakebite studies should incorporate socioeconomic and environmental peculiarities in the analysis of this serious health problem. According to the demographic indicators in the last census (IBGE, 2010), only the macro-region of Fortaleza presented urbanization rates above the average in the state of Ceará, while the other geographic areas had a significant portion of the population residing in the rural area (30\%), mainly in the macro-regions of Sertão Central and Litoral Leste/Jaguaribe, areas of high incidence of bothropic incidents. In addition, areas of the Caatinga biome show less socioeconomic development and are characterized by intensified agricultural activities during the rainy seasons, which may increase the chances of encounters with snakes (Mise $e t$ al., 2016).

In Ceará, the Atlantic Forest is restricted to brejos-de-altitude, which are usually residual remains with altitudes above $600 \mathrm{~m}$, covered by forest type vegetation (Melo-Santos et al., 2006). The regional threats that occur in the brejos-de-altitude occur mainly because they are inserted in a region of great scenic beauty and pleasant climate. These characteristics make them historically exploited areas, attractive for ecotourism, but also suitable regions for planting subsistence crops that absorb the majority of the economically active population. An economy based on primary activities causes problems related to deforestation and the introduction of exotic species (Borges-Nojosa et al., 2019). These impacts, mainly caused by anthropic action, have caused the alteration or complete elimination of microhabitats, being the loss of habitat probably the greatest threat to biological diversity.

In many areas of Ceará, environmental degradation has already reached practically irreversible conditions, showing clear marks of desertification due to the strong impact of population growth pressure on the potential vulnerability of Caatinga's natural resources (Albuquerque et al., 2014). The State has contrasting humid and sub-humid areas due to geographical factors, such as altitude and proximity to the ocean, which alter the temperature, humidity and rainfall distribution, resulting in a landscape mosaic that dictate the distribution of snakes (Guedes et al., 2019). The study carried by Mateus et al. (2015) in Ceará found a decreasing trend in rainfall in urban and populated regions (Fortaleza), and in drier regions with less vegetated area (Sertão Central). However, in the regions of Cariri, Sobral and Litoral Leste/ Jaguaribe there was a tendency for increased rainfall, which may be affecting the distribution of snakes, especially Bothrops.

The growth observed in the number of snakebite incidents in Ceará can be attributed not only to a higher occurrence, but also to improvements in the Brazilian health information system. On the other hand, difficulties in accessing health services can contribute to the underreporting of accidents due to snakebites (Bochner et al., 2014). In addition, the incidence of snakebites may be underestimated due also to the use of traditional medicine in unreported cases. Thus, the main limitation of our study could be the reliability and precision of the notifications obtained by SINAN. A study developed by Benício et al. (2019) in Piauí found several flaws in the medical records of patients injured by snakebites, including the lack of identification of the causative species, time to care and poor clinical outcomes. However, considering the similarity with previous studies for Ceará (Feitosa, 1997, Albuquerque et al., 2013, Belmino, 2015), the data presented here seem to be consistent.

Regarding the underreporting and incomplete filling of forms, our data on the epidemiology of snakebites in the state of Ceará corroborate previous studies for the Northeast region (Saraiva et al., 2012, Fiszon \& Lima et al., 2009). These notification failures are aggravated in small municipalities in Northeastern Brazil, where qualified health professionals are usually scarce to properly collect information on envenomation cases by venomous animals (Mise et al., 2018). This failure in official records indicates the need for better training of health professionals, and the establishment of more adequate protocols for recording epidemiological information on snakebites, seeking to improve serotherapeutic care and antivenoms distribution logistics (Bochner \& De Sousa, 2019). Among the challenges for effective monitoring of snakebites in Brazil, its continental 
dimension and demographic, socioeconomic and environmental diversity stand out, resulting in difficulties in managing the distribution of antivenom at a local operational level (Bochner et al., 2014, Chippaux, 2015). Thus, it is essential to collect epidemiological data that assist in the seasonal anticipation of the number and location of cases.

\section{Conclusion}

Mandatory snakebite cases reporting appears to be a useful tool for improving antivenom management. However, local studies must be continued to consider the variability of the circumstances of the accident and to refine the necessary measures for its management. The pattern of snakebites in Ceará is similar to the one observed in other northeastern states, characterizing this envenomation as a regional public health problem, especially for the semi-arid municipalities, which indicates that future studies evaluating anthropic influence and environmental factors can define priority risk areas for this envenomation.

\section{Acknowledgments}

The authors express their gratitude to Coordenadoria de Vigilância em Saúde of Secretaria Estadual de Saúde do Ceará (COVIG/SESA/CE) and Núcleo de Controle de Vetores (NUVET/COVIG/SESA) for providing the epidemiological data access. The authors would like to thank to Arthur Machado Geiger Dias de Moraes for revising in the English language.

\section{References}

Albuquerque, E. L. S., de Souza, M. J. N., de Medeiros, C. N., de Sousa, F. J. \& de Lima, K. A. (2014). Perfil geossocioeconômico: um olhar para as macrorregiões de planejamento do estado do Ceará. Fortaleza, IPECE https://www.researchgate.net/publication/282705908_Perfil_geosso cioeconomico_Um_olhar_para_as_macrorregioes_de_planejamento_do_estado_do_Ceara

Albuquerque, P. L. M. M., Silva Júnior, G. B., Jacinto, C. N., Lima, C. B., Lima, J. B. et al. (2013). Epidemiological profile of snakebite accidents in a metropolitan area of Northeast Brazil. Rev. Inst. Med. Trop. Sao Paulo, 55(5), 347-351.

Bastos, F. H., Cordeiro, A. M. N. \& Da Silva, E. V. (2017). Aspectos geoambientais e contribuições para estratégias de planejamento ambiental da Serra do Baturité/CE. Rev. Anpege, 13(21), 63-198.

Belmino, J. F. B. (2015) Epidemiologia dos acidentes ofídicos, Estado do Ceará, Brasil (2007-2013). Centro de Educação e Saúde, Universidade Federal de Campina Grande. http://dspace.sti.ufcg.edu.br:8080/jspui/bitstream/riufcg/1246/1/JOS\%C3\%89\%20FRANSCISDAVID\%20BARBOSA\%20BELMINO\%20DISSERTA\%C3\%87\%C3\%830\%20PPGCNBio\%202015.pdf

Benício, R. A., Carvalho, L. S. \& Fonseca, M. G. (2019). Venomous animals of state of Piauí: epidemiology of accidents and list of medical importance species. Rev. Bras. Zoo, 20(1), 1-14.

Bochner, R. \& De Souza, C. M. V. (2019). Divergences between the Brazilian national information systems for recording deaths from venomous animals. $J$ Venom Anim Toxins Incl Trop Dis., 25, e143018.

Borges-Nojosa, D. M., Lima, D. C., Borges-Leite, M. J., de Castro, D. P., \& de Lima, A. V. P. (2019). Mata Atlântica do Ceará: herpetofauna ameaçada e estratégias de conservação. In: Abraão, C. R., De Moura, G. J. B., De Freitas, M. A. \& Escarlate-Tavares, F. (Orgs). Plano de ação nacional para conservação da herpetofauna ameaçada da Mata atlântica nordestina. ICMBIO. https://www.icmbio.gov.br/portal/images/stories/docs-pan/pan-herpetofauna-donordeste/1-ciclo/pan-herpetofauna-do-nordeste-livro.pdf

Chaves, L. F., Chuang, T. W., Sasa, M., \& Gutiérrez, J. M. (2015). Snakebites are associated with poverty, weather fluctuations, and El Niño. Sci. Adv., 1(8), e1500249.

Chippaux, J-P. (2012). Epidemiological investigation on envenomation: from theory to practice. J. Venom Anim. Toxins Incl. Trop. Dis., 18(4), 446-450.

Chippaux, J-P. (2015). Epidemiology of envenomations by terrestrial venomous animals in Brazil based on case reporting: from obvious facts to contingencies. J Venom Anim Toxins Incl Trop Dis., 21, 1-17.

Chippaux, J-P. (2017). Incidence and mortality due to snakebite in the Americas. PLoS Negl. Trop. Dis., $11(6)$, e00056622017.

Costa, M. K. B. D., Fonseca, C. S. D., Navoni, J. A., \& Freire, E. M. X. (2019). Snakebite accidents in Rio Grande do Norte state, Brazil: epidemiology, health management and influence of the environmental scenario. Trop. Med. Int. Health, 24(4), 432-441.

Da Silva, A. M., Bernarde P. S. \& Abreu, L. C. (2015). Accidents with poisonous animals in Brazil by age and sex. Rev. Bras. Crescimento Desenvolv. Hum., 25(1), 54-62. 
Di Pietro, D. O., Williams, J. D., Cabrera, M. R., Alcalde, L., Cajade, R., \& Kacoliris, F. P. (2020). Resource partitioning in a snake assemblage from eastcentral Argentina. An. Acad. Bras. Cienc., 92.

Feitosa, R. F. G., Melo, I. M. L. M. \& Monteiro, H. S. A. (1997). Epidemiologia dos acidentes por serpentes peçonhentas do Estado do Ceará - Brasil. Rev. Soc. Bras. Med. Trop., 30, 295-301.

Fiszon, J. T. \& Bochner, R. (2008). Subnotificação de acidentes por animais peçonhentos registrados pelo SINAN no Estado do Rio de Janeiro no período de 2001 a 2005. Rev. Bras. Epidemiol., 11(1), 114-27.

França, R. C. \& França, F. G. R. (2019). Spatial patterns of snake diversity in an urban area of northeast Brazil. Herpetol. J., 29, $274-281$.

Fry, B.G. (2018). Snakebite: when the human touch becomes a bad touch. Toxins, 10(170), 1-24.

Guedes, T. B., Nogueira, C. \& Marques, O. A. V. (2019). Diversity, natural history, and geographic distribution of snakes in the Caatinga, Northeastern Brazil. Zootaxa, 3863(1), 1-93.

Gutiérrez, J. M., Calvete, J. J., Habib, A. G., Harrison, R. A., Williams, D. J., et al. (2017). Snakebite envenoming. Nat. Rev. Dis. Primers, 3(1), 1-21.

Hoyos, M. A. \& Almeida-Santos, S. M. (2016). The South-American rattlesnake Crotalus durissus: feeding ecology in the central region of Brazil. Biota Neotrop., 16(3), e20140027.

Instituto Brasileiro de Geografia e Estatística (IBGE). (2019). População Estimada - Ceará. 2019. https://cidades.ibge.gov.br/brasil/ce/panorama

Lacerda, N. P., Da Silva, G. R., Silva Júnior, A. D. F., Cavalcanti, B. C., Da Slva, C. R., et al. (2017). Registros de acidentes com animais peçonhentos (aranhas, escorpiões e serpentes) no município João Pessoa. Rev. Uningá, 51(1).

Lima, J. S., Martelli Júnior, H., Martelli, D. R. B., Silva, M. S. D., Carvalho, S. F. G. D., et al. (2009). Perfil dos acidentes ofídicos no norte do Estado de Minas Gerais, Brasil. Rev. Soc. Bras. Med. Trop 42, 561-564.

Lira-da-Silva, R. M., Mise, Y. F., Casais-e-Silva, L. L., Ulloa, J., Hamdan, B., et al. (2009). Serpentes de importância médica do nordeste do Brasil. Gaz. Med. Bahia, 79(1). 79, 7-20, 2009.

Lourenço-de-Moraes, R., Lansac-Toha, F. M., Schwind, L. T. F., Arrieira, R. L., Rosa, R. R., et al. (2019). Climate change will decrease the range size of snake species under negligible protection in the Brazilian Atlantic Forest hotspot. Sci. Rep., 9(1), 1-14.

Mateus, A. E., Costa, I. M., Da Silva, D. F., \& Lopes, J. R. F. (2015). Perspectivas em variáveis meteorológicas para o Estado do Ceará. Rev. Bras. Geog. Fis., $8(5), 1383-1392$.

Melo Santos, A. M., Cavalcanti, D. R., Silva, J. M. C. D., \& Tabarelli, M. (2007). Biogeographical relationships among tropical forests in north-eastern Brazil. J. Biogeogr., 34(3), 437-446.

Minghui, R., Malecela, M. N., Cooke, E., \& Abela-Ridder, B. (2019). Who's snakebite envenoming strategy for prevention and control. Lancet Glob. Health, 7(7), e837-e838.

Mise, Y. F., Lira-da-Silva R. M. \& Carvalho, F. M. (2007). Envenenamento por serpentes do gênero Bothrops no Estado da Bahia: aspectos epidemiológicos e clínicos. Rev. Soc. Bras. Med. Trop., 40(5), 569-573.

Mise, Y. F., Lira-da-Silva R. M. \& Carvalho, F. M. (2016). Agriculture and snakebite in Bahia, Brazil - an ecological study. Ann. Agric. Environ. Med., 23(3), $416-419$.

Mise, Y. F., Lira-da-Silva R. M. \& Carvalho, F. M. (2018). Time to treatment and severity of snake envenoming in Brazil. Rev. Panam. Salud Publica, 42, e52.

Mise, Y. F., Lira-da-Silva R. M. \& Carvalho, F. M. (2019). Fatal snakebite envenoming and agricultural work in Brazil: a case-control study. Am. J. Trop. Med. Hyg., 100(1), 150-154.

Murray, K. A., Martin, G. \& Iwamura, T. (2020). Focus on snake ecology to fight snakebite. The Lancet, 395(10220), e142020.

Oliveira, N. D. R., Sousa, A. C. D. R., Belmino, J. F. B., Furtado, S. D. S., \& Leite, R. D. S. (2015). The epidemiology of envenomation via snakebite in the State of Piauí, Northeastern Brazil. Rev. Soc. Bra.s Med. Trop., 48, 99-104.

Saraiva, M. G., Oliveira, D. D. S., Coutinho, L. A. S. D. A., \& Guerreiro, J. V. (2012). Perfil epidemiológico dos acidentes ofídicos no Estado da Paraíba, Brasil, 2005 a 2010. Epidemiol. Serv. Saude, 21(3), 449-456.

Simpson, I. \& Norris, R. (2009). The global snakebite crisis: a public health issue misunderstood, not neglected. Wild Environ. Med., 9(20), 43-56.

Sistema de Informação de Agravos de Notificação (SINAN). (2019). Casos de acidentes por animais peçonhentos: Ceará (2007-2019). Ministério da Saúde (BR), Secretaria de Vigilância em Saúde. http://tabnet.datasus.gov.br/cgi/deftohtm.exe?sinannet/cnv/animaisce.def

Tavares, A. V., Araújo, K. A. M. D., Marques, M. R. D. V., \& Leite, R. (2020). Epidemiology of the injury with venomous animals in the state of Rio Grande do Norte, Northeast of Brazil. Cien. \& Saude Col., 25, 1967-1978.

World Health Organization (WHO). (2019). Snakebite envenoming: a strategy for prevention and control. https://www.who.int/snakebites/resources/who-cdsntd-nzd-2019.03/en/ 